\title{
Isolation and Characterization of Wild Type Acetobacter xylinum from Nata de Coco Industry in Surakarta Residency
}

\author{
E R Karuni ${ }^{1}$, A M Sari ${ }^{1, *}$, A Nursiwi ${ }^{1}$ and A P Sanjaya ${ }^{1}$ \\ ${ }^{I}$ Departement of Food Science Technology, Sebelas Maret University, 36A Ir. Sutami Street, Pucangsawit, Jebres, \\ Surakarta, Central Java, Indonesia \\ *Corresponding author. Email: ardhea_ms@staff.uns.ac.id
}

\begin{abstract}
Starter quality is one of critical factor in nata de coco fermentation. The isolation of nata de coco starter was needed in order to obtain pure isolate. In this research, isolation was conducted to 3 different starters from small nata de coco industries in Surakarta Regency (SME). The isolation produced 13 isolates which have 2 different shapes, where 8 isolates were rods and 5 were coccobacilli. All of these 13 isolates were Gram negative. Seven isolates have positive catalase and 6 isolates negative. However only one isolate showed a positive result in acetic acid production using $\mathrm{CaCO} 3$-etanol (Frateur) medium, ethanol over oxidation using Carr medium and bacterial cellulose production using HS (Hestrin-Scharmm) broth, namely isolate SRG 3A. Based on such result, isolate which has similar characteristics with Actobacter xylinum in references is only 1 isolate, and that is isolate obtained from SME in Sragen, SRG 3A. Both isolate SRG 3A and Actobacter xylinum have rods shape, Gram negative, catalase positive, producing acetic acid, over oxidized ethanol and bacterial cellulose.
\end{abstract}

Keywords: Isolation, Acetobacter xylinum, Acetic acid bacteria, Characterization.

\section{INTRODUCTION}

Nata de coco industry in SMEs (Small and Medium Enterprises) in Surakarta residency have started to develop. Some SMEs though encounters obstacles during production phase, causing a decrease in the quality of nata and a decrease in its direct production quantity. The highest yield obtained from one SME is only $70 \%$. The critical factor in the production process is the quality of the bacteria used as a starter. These constraints occur due to lack of education regarding the maintenance repair of contaminated starter. Factors that affect the process of fermentation are environment $\mathrm{pH}$, fermentation temperature, the existence of oxygen and substrate for these microorganisms. Control factors are needed in order to create the conditions for growth and the production of optimum position of that which is desirable [1]. Thus it is necessary to isolate bacteria from nata de coco starter of the SMEs to obtain pure isolates that have been adapted to suit the conditions of the SME production environment where samples are taken. The isolate is expected to be the SME local isolate and can reduce spending to buy a new starter which may not necessarily be able to adapt to the condition of SME environment. After obtaining isolates, several tests were carried out to determine the morphological and physiological characteristics of the isolates and the ability to produce bacterial cellulose. Based on these results, then the characteristic approach of isolates with Acetobacter xylinum was carried out according to the reference.

\section{MATERIAL AND METHODS}

\subsection{Material}

This research used nata de coco starter from Matahari SME, Baki District, Sukoharjo Regency (BKI); Maju Jaya SME, Sambirejo District, Sragen Regency (SRG) and Bapak Pras SME, Sukoharjo Regency, Bekonang District (BKG).

\subsection{Isolation Method}

The isolation was carried out using Aydin and Aksoy [2] methods. One $\mathrm{ml}$ of nata de coco starter sample was 
statically incubated in $100 \mathrm{ml}$ of Hestrin Scharmm (HS) broth $(2.0 \%$ glucose; $0.5 \%$ peptone; $0.5 \%$ yeast extract; $0.27 \% \mathrm{Na}_{2} \mathrm{HPO}_{4}$ and 0.115 citric acid in w/v) for 7 days at $30^{\circ} \mathrm{C}$. Culture with bacterial cellulose layer on the surface of the medium was chosen to be isolated on HS agar medium using streak plate method and incubated for 3 days at $30^{\circ} \mathrm{C}$. Colonies that were separated were taken and etched on the HS slanting agar as storage medium. The isolates were incubated for 24 hours and then their morphology and physiology were identified.

\subsection{Morphology and Physiology Identification Methods}

The tests conducted to determine the morphology and physiology of isolates referring to the morphology and physiology of Acetobacter xylinum according to Holt et al (1994). Morphological identification is carried out by observing cell shape [3, 4] and Gram identification by Gram staining method [5]. Physiological tests including catalase tests, acetic acid production tests, ethanol overoxidation tests and cellulose production tests. Catalase test used $\mathrm{H}_{2} \mathrm{O}_{2} 3 \%$ reagent. Positive results are shown by the reaction of air bubbles forming in isolates, immediately after the isolates are dripped by reagents [6]. The acetic acid production test was carried out by growing isolates on Frateur agar medium $\left(\mathrm{CaCO}_{3}\right.$-ethanol) $(0,05 \%$ Dglucose; $0.3 \%$ peptone; $0.5 \%$ yeast extract; $1.5 \%$ $\mathrm{CaCO}_{3}, 1.2 \%$ agar and $1.5 \%$ (v/v) ethanol). Positive results are shown by the formation of clear zone around the colony, then the isolates positively produce acetic acid [7]. Ethanol overoxidation was carried out by growing isolates on Carr agar medium (2\% $\mathrm{ml}$ of ethanol (v/v), 3\% grams of yeast extract, $0.0022 \%$ grams of bromocresol green, and $2 \%$ grams of agar). The positive results of ethanol overoxidation are shown in the color change of medium from the initial color, greenish blue to yellowish green and back to greenish blue [8]. Cellulose production is carried out using HS broth and positive results are indicated by the presence of bacterial cellulose layer on medium surface. The bacterial cellulose was separated from the medium, heated with $\mathrm{NaOH} 1 \%$ for 15 minutes, washed with running water and then dried at $80^{\circ} \mathrm{C}$ for approximately 8 hours for mass identification $[8,9,10]$.

\section{RESULT AND DISCUSSION}

The starter isolation from 3 SMEs obtained 13 isolates, 7 isolates from Baki SME, 3 isolates from Sragen SME and 3 isolates from Bekonang SME. The isolates were taken from colonies which were separated from the quadrant streak plate isolation method. The results of isolation and characterization of isolates can be seen in table 1 .

\subsection{Morphology}

\subsubsection{Colony and cell shape.}

The isolate colonies obtained were round, convex and yellowish white or cream colored. The size of SRG isolate colonies is larger than the size of $\mathrm{BKI}$ and $\mathrm{BKG}$ isolates. Similar to Krusong et al [11], there are two types of colonies with different size from celluloseproducing bacteria which are Large Colony (LC) and Smooth Colony (SC).

The form of isolate cells obtained were 8 rod-shaped isolates and 5 rod-shaped and short rod-shaped isolates. The 8 rod-shaped isolates were BKI 1B, BKI 2A, BKI 2C, SRG 3B, SRG 3C, BKG 1A, BKG 1B, BKG 1C. While 5 rod-shaped and coccobacilli isolates were $\mathrm{BKI}$ 2B, BKI 3A, BKI 3B, BKI 3C, SRG 3A. The rodshaped of the 8 isolates was in accordance with Klemm et al [12] where Acetobacter xylinum cell shape resembles a rod with a rounded tip. However, in 5 isolates that had short rod and rod cell forms, resembling Maal's [13] study, where the isolates found in acetic acid bacteria isolation were rod-shaped to coccobacilli. The coccobacilli shape is the bacteria type which stands between a round (cocci) and a rod (bacilli) in term of its form.

\subsubsection{Gram indetification.}

Gram identification of bacteria was carried out to distinguish bacteria based on cell wall structure [14] Gram positive bacteria will be purple and Gram negative bacteria will be red [6]. In this study all isolates from the three SMEs were red after Gram staining. It shows that the isolates were Gram negative bacteria. This Gram negative has the same property as Acetobacter xylinum Gram (Holt et al, 1994). This is because Acetobacter xylinum belongs to Acetobacter genus which is a genus of Gram negative bacteria.

\subsection{Physiology}

\subsubsection{Catalase test.}

Catalase test aims to determine the presence of catalase enzymes in bacteria. The catalase enzyme works to prevent the free radicals oxidation that can damage or kill bacteria. Free radicals in bacteria is in the form of hydrogen peroxide $\left(\mathrm{H}_{2} \mathrm{O}_{2}\right)$ which is one of the of bacterial aerobic respiration output. So this enzyme can be found in all types of aerobic eukaryotes (Winarsi, 2007) ${ }^{[15]}$. This test would be positive if after isolates were dripped with $\mathrm{H}_{2} \mathrm{O}_{2} 3 \%$ reagent, air bubbles were formed [6].

In this research, isolates with positive catalase wre BKI 1B, BKI 2A, BKI 3B, SRB 3B, BKG 1A, BKG 1B and $B K G 1 C$. While isolates with negative catalase were BKI 2B, BKI 2C, BKI 3A, BKI 3C, SRG 3A, SRG 3C. The isolates with positive catalase have the same 
Table 1 Morphological and Physiological Observation Result of Acetobacter xylinum wild type Isolates

\begin{tabular}{|c|c|c|c|c|c|c|c|}
\hline \multicolumn{2}{|c|}{ Isolates } & Shape & $\begin{array}{c}\text { Gram } \\
\text { identification }\end{array}$ & Catalase & $\begin{array}{l}\text { Acetic acid } \\
\text { production }\end{array}$ & $\begin{array}{c}\text { Ethanol } \\
\text { overoxidation }\end{array}$ & $\begin{array}{c}\text { Cellulose } \\
\text { production }\end{array}$ \\
\hline \multicolumn{2}{|c|}{$\begin{array}{c}\text { Acetobacter } \\
\text { xylinum* }\end{array}$} & Ellipsoidal, rod & - & + & + & + & + \\
\hline \multirow[t]{7}{*}{ BKI } & 1B & Rod & - & + & N/A & N/A & N/A \\
\hline & $2 \mathrm{~A}$ & Rod & - & + & N/A & N/A & N/A \\
\hline & $2 \mathrm{~B}$ & Rod, coccobacilli & - & - & N/A & N/A & N/A \\
\hline & $2 \mathrm{C}$ & Rod & - & - & N/A & N/A & N/A \\
\hline & $3 \mathrm{~A}$ & Rod, coccobacilli & - & - & N/A & N/A & N/A \\
\hline & $3 B$ & Rod, coccobacilli & - & + & N/A & N/A & N/A \\
\hline & $3 \mathrm{C}$ & Rod, coccobacilli & - & - & N/A & N/A & N/A \\
\hline \multirow[t]{3}{*}{ SRG } & $3 \mathrm{~A}$ & Rod, coccobacilli & - & - & N/A & N/A & N/A \\
\hline & $3 B$ & Rod & - & + & + & + & $w$ \\
\hline & $3 \mathrm{C}$ & Rod & - & - & N/A & N/A & N/A \\
\hline \multirow[t]{3}{*}{ BKG } & $1 \mathrm{~A}$ & Rod & - & + & N/A & N/A & N/A \\
\hline & 1B & Rod & - & + & N/A & N/A & N/A \\
\hline & $1 \mathrm{C}$ & Rod & - & + & N/A & N/A & N/A \\
\hline
\end{tabular}

${ }^{a}$ Holt et al, 1994; Notes: $(+)=$ positive; $(-)=$ negative; $(\mathrm{N} / \mathrm{A})=$ not available/ no production; $(\mathrm{w})=$ weak/ very little production

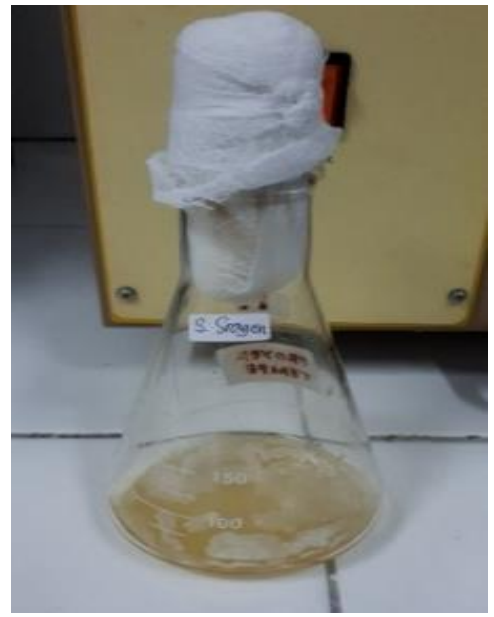

Figure 1. Cellulose production test result of SRG 3B isolate

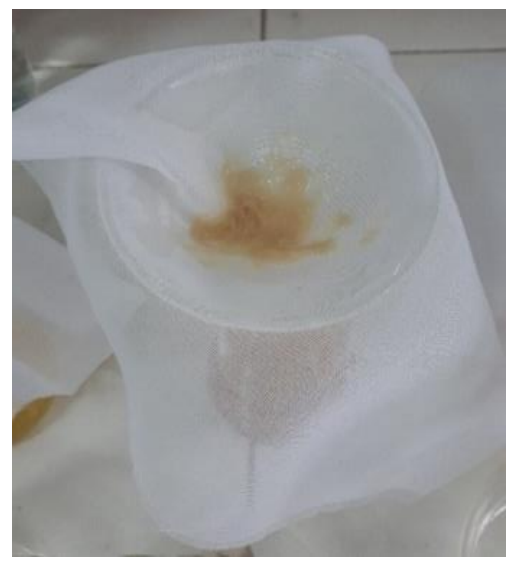

Figure 2. The layer after filtering from SRG 3B isolate

catalase properties as Acetobacter xylinum, which is positive catalase and including aerobic bacteria (Holt et al., 1994). Suwanposri (2013) also stated that cellulose- producing bacteria are bacteria with positive catalase reaction. So the isolates with negative catalase do not have the desired properties of Acetobacter xylinum. Air bubbles are formed due to $\mathrm{H}_{2} \mathrm{O}_{2}$ decomposition to $\mathrm{H}_{2} \mathrm{O}$ and $\mathrm{O}_{2}$ by catalase enzyme (Hadioetomo, 1993). The breakdown reaction of hydrogen peroxide by the catalase enzyme is as follows: $2 \mathrm{H}_{2} \mathrm{O}_{2} \rightarrow 2 \mathrm{H}_{2} \mathrm{O}+\mathrm{O}_{2}$ [16].

\subsubsection{Acetic acid production.}

Acetobacter xylinum is in the Acetobacter genus which is bacterium that can produce acetic acid as a primary metabolite [17]. The medium that can be used to identify the acetic acid production is ethanol- $\mathrm{CaCO}_{3}$ or Frateur medium. Positive test results can be observed by the changes of medium to transparent around the colony or often called the clear zone [7, 18]. In this study isolates that showed positive results were SRG 3B isolates. While other isolates did not react to the medium so the test results were negative.

\subsubsection{Ethanol over oxidation.}

Most acetic acid bacteria can oxidize ethanol to acetic acid [19]. The acetic acid produced from the ethanol oxidation can be further oxidized to water and oxygen. This characteristic is commonly referred to as over oxidation [20]. This over oxidizer ability can be a differentiator between Acetobacter and Gluconobacter [21]. The method used to identify the occurrence of acetic acid is to grow isolates in the Carr medium.

Identification of ethanol over oxidation can be seen from changes in medium color. Positive results will change the color of the medium from greenish blue to yellow and back to greenish blue.

The identification results of isolates grown on Carr medium showed positive results, which is the change in 
medium color from blue to greenish yellow on the second day then changed to bluish green on the fourth day of incubation. Discoloration in this medium only occurred in SRG 3B isolates. It shows that SRG 3B isolates have the same properties as Acetobacter xylinum (Holt et al, 1994). In accordance with the same biochemical testing conducted by Son et al [8] on Acetobacter xylinum $\mathrm{KJ}-1$ isolates also showed positive results of ethanol over oxidation.

\subsubsection{Bacterial cellulose production.}

In this study, isolates grown in HS broth statically for 7 days produced a thin layer floating on the medium. The appearance of the layer can be seen in Figure 1 . Based on the method, the cellulose formed in the liquid medium is separated from the medium, washed and then dried to identify its weight. The formed layer has a very fragile and easily broken structure, this can be seen in Figure 2. When the layer is separated from the medium by filtering it using filter cloth, the layer is destroyed and its appearance resembles pulp. Some possibilities that occur in this study include the isolates condition that are not optimal due to the original conditions on the SMEs which was very heterogeneous as well as the unsuitable medium conditions to support cellulose growth.

\section{CONCLUSION}

The isolation results obtained from three nata de coco SMEs were 13 isolates taken from separate colonies. Some of these colonies have non homogeneous cell forms. Based on morphological and physiological tests of one isolate from Sragen SME (SRG 3A), it has similarities with the reference morphology and physiology. The similarity lies in the colonies shape, cell shape, bacterial Gram color, acetic acid production and ethanol over oxidation. One slightly different trait is bacterial cellulose production. The production of bacterial cellulose by isolates is very low in quantity and poor in quality.

\section{REFERENCES}

[1] Desrosier, N.W. 1988. Teknologi Pengawetan Pangan. UI Press. Jakarta.

[2] Aydin, Y.A., and Aksoy, N.D. 2009. Isolation of Cellulose Producing Bacteria from Wastes of Vinegar Fermentation. Proceedings of the World Congress on Engineering and Computer Science. San Francisco, USA.

[3] Fardiaz, S. 2014. Mikrobiologi Pangan. Universitas Terbuka. Tangerang Selatan.

[4] De Ley, J., J. Swings and F. Gossele'. 1984. Genus I. Acetobacter Beijerinck 1898, 215AL. In Bergey's Manual of Systematic Bacteriology,vol. 1, pp. 268-274. (N. R. Krieg \& J. G. Holt, eds.). Baltimore, Williams \& Wilkins.
[5] Hadiotomo, R.S. Mikrobiologi Dasar dalam Praktek: Teknik dan Prosedur Dasar Laboratorium. PT Gramedia. Jakarta.

[6] Lay, B.W. 1994. Analisis Mikrobiologi di Laboratorium. Raja Grafindo Persada. Jakarta.

[7] Tyagi, N., and S. Suresh. 2013. Isolation and Characterization of Cellulose Producing Bacterial Strain from Orange Pulp. Advanced Materials Research Vol. 626. ISSN: 16628985.

[8] Son, C., Chung, S., Lee J., and Kim S. 2002. Isolation and Cultivation Characteristics of Acetobacter xylinum KJ-1 Producing Bacterial Cellulose in Shaking Cultures. Journal Microbiol. Biotechnol. 12 (5).

[9] Keshk, S. M. A. S., and Sameshima, K. 2005. Evaluation of Different Carbon Sources for Bacterial Cellulose Production. Jurnal Biotechnology. Vol. 4 (6)

[10] Suwanposri, A., Yukphan, P., Yamada, Y. and Ochaikul, D. 2013. Identification and Biocellulose Production of Gluconacetobacter Strains Isolated from Tropical Fruits in Thailand. Maejo International Journal of Science and Technology ISSN 1905-7873.

[11] Krusong, W., Jindaprascrt, A., and Yoshida, T. 2001. Acetobacter xylinum DK: A Cellulose Gel Producing Strain with Two Distinctive Types of Colony for Agitated Cultivation. King Mongkut's Institute of Technology Ladkrabang Journal Vol. December.

[12] Klemm, D., Kramer, F., Moritz, S., Lindstrom, T., Ankerfors, M., Gray, D. and Dorris, A. 2011. Nanocelluloses: A New Family of Nature-Based Materials. Angewandte Chemie Internartional Edition 2011, 50.

[13] Maal, K.B., Shafiei, R., Kabiri, N. 2010. Production of Apricot Vinegar Using an Isolated Acetobacter Strain from Iranian Apricot. World Academy of Science, Engineering and Technology International Journal of Nutrition and Food Engineering. Vol. 4 No. 11.

[14] Waluyo, L. 2005. Mikrobiologi Umum. MM Press. Malang.

[15] Winarsi H. 2007. Antioksidan alami dan radikal bebas. Penerbit Kanisius. Jogyakarta.

[16] Volk and Wheeler. 1993. Mikrobiologi Dasar. Erlangga. Jakarta.

[17] Pambayun, R. 2002 .Teknologi Pengolahan Nata de Coco. Kanisius. Yogyakarta.

[18] Sharafi, S. M., Maal, K. B. 2010. Isolation, Characterization and Optimization of Indigenous Acetic Acid Bacteria and Evaluation of Their Preservation Methods. Iranian Journal of Microbiology. Vol. 2 No. 1.

[19] Cleewerk, I. 2008. Improved Classification and Identification of Acetic Acid Bacteria Based on Molecular Techniques. Faculty of Sciences Department of Biochemistry, Physiology and 
Microbiology Laboratory of Microbiology Gent University.

[20] Kersters, K., Lisdiyanti. P., Komagata, K., and Swings, J. 2006. The Family Acetobacteraceae: The Genera Acetobacter, Acidomonas, Asaia,

Gluconacetobacter, Gluconobacter and Kozakia. Prokaryotes 5:163-200 Chapter 3.1.8.

[21] Heikefelt, C. 2011. Chemical and Sensory Analyses of Juice, Cider and Vinegar Produced from Different Apple Cultivars. Thesis. SLU. Swedish University of Agricultural Sciences, Alnarp

[22] Rangaswamy, B. E., Vanitha, K. P., and Hungund, B.S. 2015. Microbial Cellulose Production from Bacteria Isolated frim Rotten Fruit. International Journal of Polymer Science. Vol. 2015.

[23] Bellankimath, A., Katti, A., Hemalata, V. B. and Meti, B. S. 2017. Isolation and Characterization of the Indigenous Acetic Acid Bacteria from Western Ghats Soil Sample. International Journal of Current Microbiology and Applied Sciences. Volume 6 Number 9. 